\title{
Pantetheinase Activity and Cysteamine Content in Cystinotic and Normal Fibroblasts and Leukocytes
}

\author{
SHELDON ORLOFF, JEAN DEB. BUTLER, DAVID TOWNE, ANIL B. MUKHERJEE, AND \\ JOSEPH D. SCHULMAN ${ }^{(52)}$ \\ Section on Human Biochemical and Developmental Genetics, NICHD, NIH, Bethesda, Maryland, USA
}

\begin{abstract}
Summary
Cysteamine is the most effective agent known for the reduction of the elevated cystine content of cells from patients with cystinosis. A defect in endogenous cysteamine generation could account for many of the metabolic features of this disorder. To test this hypothesis, we have developed improved methods for measuring pantetheinase (cysteamine-generating) activity and intracellular cysteamine levels and used these methods to measure such parameters in cystinotic and normal leukocytes and cultured skin fibroblasts. Pantetheinase activity as defined in the text was similar in extracts of cystinotic and normal cells [leucocytes, normal, $78 \pm 15$ (S.E.), cystinotic, $56 \pm 6.4$; fibroblasts, normal, $9.4 \pm 1.5$; cystinotic, $7.7 \pm 1.7 \mid$. Cysteamine levels were normal in leukocytes from cystinotics receiving no cysteamine or doses of oral cysteamine too low to reduce leukocyte cystine content. The results indicate that the cause of cystinosis is unlikely to be related to a failure to generate or sustain normal intracellular cysteamine levels.
\end{abstract}

\section{Speculation}

Cysteamine is an extremely effective cystine depleting agent for cystinotic fibroblasts in vitro and can greatly reduce cystinotic leukocyte cystine content in vivo. Its pharmacologic properties suggest that it might prove to be of value in the therapy of cystinosis. However, we do not believe that a defect in endogenous cysteamine generation is a characteristic of cystinotic cells. The eventual elucidation of the cystinotic defect may require analysis of the permeability characteristics of cystinotic lysosomes or the discovery of presently unidentified pathways for lysosomal metabolism of cystine.

Cystinosis, a metabolic disease inherited as an autosomal recessive trait, is characterized by abnormal intralysosomal accumulation of $\mathrm{L}$-cystine in most cells of the body $(32,36)$. The progressive accumulation of cystine leads to eventual destruction of cells, most notably in the kidney, and terminal renal failure by the second decade of life is characteristic of the most severe and common nephropathic variant. The fundamental biochemical defect underlying this disorder has yet to be elucidated.

The apparently major mechanism for reduction of cystine in normal cells involves enzymatically catalyzed glutathione-cystine transhydrogenation. Studies of this and other disulfide reducing systems have failed to define the abnormality causing cystinosis $(28,29,44-47)$.

Cysteamine [mercaptoethylamine (MEA)] is a naturally occurring, freely soluble sulfhydryl compound which readily penetrates many biologic membranes. When supplied exogenously, it is highly effective in reducing the elevated cystine content of cystinotic cells in vitro, presumably by entering the cystinotic lysosomes and reducing cystine to the smaller and more soluble cysteine. A suggested mechanism for cysteamine-mediated cystine depletion has been discussed previously (42). In this model, cysteamine acts as a hydrogen carrier between cytoplasmic-reduced glutathione (which appears to penetrate membranes poorly) and intralysosomal cystine. A genetic deficiency in endogenous cysteamine generation might therefore lead to diminished capacity for intralysosomal reduction of cystine to cysteine, a molecule to which the lysosomal membrane should be permeable (33) and hence could be the fundamental etiology of abnormal cystine accumulation in cystinosis.

Cysteamine (Fig. 1) is generated in animals by only one known mechanism: the irreversible enzymatic cleavage of pantetheine (PTSH). Pantetheinase activity has been demonstrated by Abiko and associates $(1-3,26)$ by Dupré et al., and by Cavallini in studies on a limited variety of mammals $(4,6,8,9,11,14-17)$. There is some evidence that pantetheinase is present in both soluble and lysosomal-microsomal cell fractions. This enzyme has not previously been described in human cells or tissues.

Pantetheinase activity has been determined by several methods. One involves quantitation of pantothenic acid (PoA), an end product of PTSH cleavage, using a microbiological assay in which PoA is a necessary growth factor (e.g., using Lactobacillus arabinosus) $(2,5,9,10,39)$. The radiochemical assay of Dupre et al. $(6$, 14-17) utilizes labeled PTSH as substrate and measures radioactive product after chromatographic separation from PTSH. A pHStat method has also been proposed (11). The first method is time consuming and proved erratic in our hands, whereas the radiochemical assay requires an expensive radiolabeled substrate which must be specially synthesized. We therefore developed a new assay system for determination of low levels of pantetheinase activity in small cell samples; our assay involves rapid quantitation of MEA on an amino acid analyzer after generation from PTSH and reaction with $N$-ethylmaleimide (NEM).

The present report describes our use of this new method to determine panthetheinase activity and define certain properties of this enzyme in extracts of cultured skin fibroblasts and freshly harvested leukocytes from normal and cystinotic subjects. We also attempted to directly measure cysteamine levels in these cells.

\section{MATERIALS AND METHODS}

\section{TISSUE CULTURE}

Skin fibroblasts matched for passage number from normal, cystinotic, and heterozygous (for cystinosis) subjects were grown to confluency at $37^{\circ} \mathrm{C}$ in a $5 \% \mathrm{CO}_{2} / 95 \%$ air atmosphere in roller bottles or $75 \mathrm{~cm}^{2}$ plastic Falcon tissue culture flasks. They were cultured in Eagle's minimal essential medium with added nonessential amino acids, $2 \mathrm{mM}$ glutamine, $10 \%$ fetal calf serum, and $100 \mu \mathrm{g} / \mathrm{ml}$ neomycin, penicillin, and streptomycin. At harvesting, the medium was decanted, the monolayer was washed three times with isotonic phosphate-buffered saline, and the cells were detached with brief exposure to $0.25 \%$ trypsin in PBS at $37^{\circ} \mathrm{C}$. A small amount of fresh medium was added to stop the reaction, and the detached cells were collected and washed three times with cold phosphate-buffered saline using repetitive low-speed centrif- 


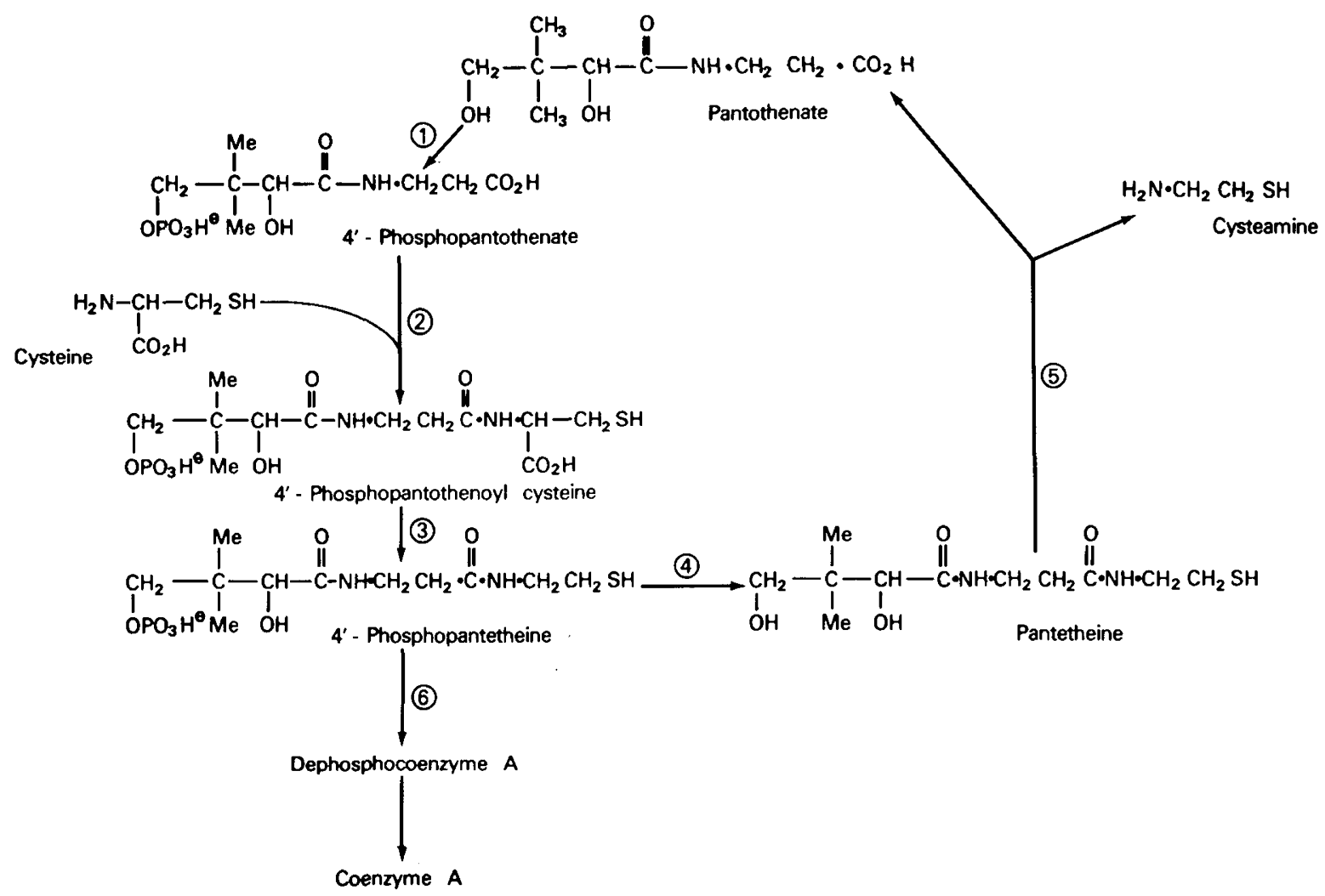

Fig. 1. The pantetheinase reaction (reaction 5) and related metabolic interconversions.

ugation and gentle resuspension. The pellet was then sonicated in assay buffer at $4^{\circ} \mathrm{C}$ in 10 -sec bursts for a total of $60 \mathrm{sec}$. The sonicate was kept at $4^{\circ} \mathrm{C}$ and used within several hours for enzyme assay. Total protein was determined by the method of Lowry et al. (23).

\section{LEUKOCYTE [WHITE BLOOD CELL (WBC)] PREPARATION}

Five to $10 \mathrm{ml}$ of freshly drawn heparinized blood was obtained from normal volunteers, cystinotic patients, and their parents (obligate heterozygotes). Blood was mixed with an equal volume of $4 \%$ dextran or Plasmagel. After sedimentation at $25^{\circ} \mathrm{C}$ for approximately $30 \mathrm{~min}$, the supernatant was collected, the WBC concentrated by centrifugation, and the residual erythrocytes removed using three hypotonic lyses $(30,37)$. The WBC pellet was then resuspended in cold buffer and sonicated and used like the fibroblasts.

\section{ASSAY TECHNIQUES}

All reagents were highest purity or Analar grades. Commercially obtained pantethine (PTSS) was checked for purity using a Beckman 121M amino acid analyzer and high-voltage electrophoresis and found to have a variety of contaminants. Repurification was achieved using Dowex 50W, 8 X 200 to $400 \mathrm{mesh}, \mathrm{H}+$ resin (Biorad) in a $0.6 \times 4 \mathrm{~cm}$ column. One $\mathrm{ml}$ of a $50 \mathrm{mg} / 5 \mathrm{ml} \mathrm{H}_{2} \mathrm{O}$ stock solution of PTSS (kept frozen) was applied to the column and eluted with $1 \mathrm{ml}$ of $0.1 \mathrm{~N} \mathrm{HCl}$ and $2.5 \mathrm{ml}$ of $\mathrm{H}_{2} \mathrm{O}$. Buffer was added to give a final PTSS concentration of $4 \mathrm{mM}$, and $\mathrm{pH}$ was adjusted to 7.6 for use in the assay. [Except where noted, buffer was $0.05 \mathrm{M}$ potassium phosphate ( $\mathrm{pH} 7.6)]$.

To reduce PTSS to PTSH, dithiothreitol (DTT) was used. Like PTSS, the DTT was passed over a Dowex 50 column and eluted with water. It was then diluted in buffer to give an $8 \mathrm{mM}$ solution and was used immediately in the assay. Reducing power is lowered approximately $10 \%$ (as checked by DTNB) by this purification.

In the pantetheinase assay, all solutions were equilibrated with nitrogen, and the reaction was carried out under nitrogen in a 1.5 $\mathrm{ml}$ capped Beckman conical Microfuge tube. PTSS $(0.2 \mu$ moles $)$ and $0.4 \mu$ moles DTT in buffer were combined and vortexed, and after 5 min EDTA was added to a final concentration of $10^{-3} \mathrm{M}$. EDTA was used to inhibit possible subsequent oxidation of generated cysteamine to hypotaurine $(7,12,13-20,22,48,50)$. After $10 \mathrm{~min}$ of preincubation at $37^{\circ} \mathrm{C}$, cell extract in buffer preequalibrated with nitrogen was added, the tube was gassed with nitrogen, and the cap was tightened. Final rection volume was $0.5 \mathrm{ml}$. The mixture was generally incubated for $90 \mathrm{~min}$ (WBC) or $240 \mathrm{~min}$ (fibroblasts) with oscillation in a water bath at $37^{\circ} \mathrm{C}$; inversion of the tube was carried out every $30 \mathrm{~min}$. At the conclusion of incubation, the reaction mixture was placed on ice and an additional $0.2 \mu$ mole of buffered DTT $(8 \mathrm{mM})$ was added. After 10 min, $2 \mu$ moles NEM ( $20 \mathrm{mM}$ in buffer) were added with mixing. After $15 \mathrm{~min}$, the reaction was stopped with $1 / 4$ volume of $20 \%$ sulfosalicylic acid. After centrifuging, the reaction tube in a Beckman Microfuge for $5 \mathrm{~min}$, NEM-MEA was quantitated in the supernatant by automated ion exchange chromatography using a Beckman $121 \mathrm{M}$ amino analyzer.

The conditions below were used on the amino acid analyzer to permit quantitation of NEM-MEA, and by utilizing two columns and automatic sample injection, it was possible to assay an average of one sample every $35 \mathrm{~min}$. Jacketed $15 \mathrm{~cm}$ column assemblies were packed with Durrum DC-6A resin to form a 0.28 by $7.0 \mathrm{~cm}$ bed. Column temperature was $50^{\circ} \mathrm{C}$. One hundred $\mu$ liters of sample were injected onto the column. Flow rate was adjusted to approximately $10.5 \mathrm{ml} / \mathrm{hr}$. All buffers contained 5 drops of pentachlorophenol solution, $5 \mathrm{mg} / \mathrm{ml}$ in ethanol (Pierce Chemical Co.), and 0.6 to $1.2 \mathrm{ml}$ of Brij 35 detergent, 30\% solution (Pierce Chemical $\mathrm{Co}$.) per liter. The sequence and timing of sodium citrate buffers were as follows: $0.44 \mathrm{~N}(\mathrm{pH} 4.00)$ for $3 \mathrm{~min} ; 0.40 \mathrm{~N}(\mathrm{pH}$ 5.03 ) for $7 \mathrm{~min}$; and $1.0 \mathrm{~N}(\mathrm{pH} 6.40$ ) for $40 \mathrm{~min}$. NEM-MEA eluted as an isolated peak with a retention time of approximately 47 min. NEM-MEA (0.1 to 0.2 nmoles) applied to the column was the minimum which could be reliably quantitated. NEMMEA standards were made using known amounts of MEA, adding DTT, and reacting with excess NEM under nitrogen.

Appropriate blanks for the panthetheinase assay contained either no enzyme or enzyme which had been boiled for $60 \mathrm{sec}$; both gave equivalent results and yielded no measurable NEMMEA. Appropriate internal and external standards of NEM-MEA 
and MEA were used to confirm the quantitative nature and reliability of the assay. Addition of cystine to levels expected in cystinotic cell extracts did not affect activity in this assay.

\section{ATTEMPTS TO ASSAY MEA BY HIGH-VOLTAGE ELECTROPHORESIS (HVE)}

In preliminary experiments, NEM-MEA as well as other sulfhydryl, disulfide, mixed disulfide, and NEM-sulfhydryl amino acid derivatives used as standards were spotted on Whatman $3 \mathrm{MM}$ paper, subjected to electrophoresis for $2 \mathrm{hr}$ at 4000 volts using a $7.8 \%$ formic acid bath, and identified after ninhydrin staining. Rough quantitation of MEA could be achieved in this system if the MEA was previously reacted with radiolabeled NEM (either ${ }^{14} \mathrm{C}$ or ${ }^{3} \mathrm{H}$ ) of known specific activity (24), an aliquot spotted on top of a nonradioactive NEM-MEA standard, and after HVE, the area corresponding to NEM-MEA dried, cut out, and radioactivity measured in a scintillation counter. To confirm identification, the radioactive NEM-MEA spot could be eluted, reapplied to Whatman $3 \mathrm{MM}$, followed by ascending chromatography in butanol/ acetic acid $/ \mathrm{H}_{2} \mathrm{O}(12 / 3 / 5)$. However, attempts to accurately quantify the MEA produced in the pantetheinase assay using radioactive NEM followed by HVE yielded results much inferior to the amino acid analyzer measurement of unlabeled end product described above.

\section{ASSAY OF CYSTEAMINE LEVELS IN CYSTINOTIC AND NORMAL CELLS}

Leukocytes, usually from $20 \mathrm{ml}$ heparinized blood, were prepared by dextran or Plasmagel sedimentation and hypotonic lysis as described above. The leukocyte pellet in $250 \lambda$ of $0.9 \%$ sodium chloride was sonicated for 5 to $10 \mathrm{sec}$ and mixed with $50 \lambda$ of DTT solution $(23.1 \mathrm{mg} / \mathrm{ml})$ in $100 \mathrm{mM}$ potassium phosphate buffer (pH 8.0). After $10 \mathrm{~min}, 150 \lambda$ of freshly dissolved NEM solution $(24 \mathrm{mg} / \mathrm{ml})$ in $10 \mathrm{mM}$ potassium phosphate $(\mathrm{pH} 8.0)$ was added. Fifteen to 20 min later, the sample was acidified with 50 $\lambda$ of $40 \%$ SSA in water. After centrifugation, NEM-MEA was determined on the amino acid analyzer as described above. Fibroblast cysteamine levels were examined analogously on washed, trypsinized cells. The method gives reliable quantitation of an internal MEA standard from a fraction of a nanomole to at least $200 \mathrm{~nm} / \mathrm{ml}$.

\section{RESULTS}

\section{PANTETHEINASE ACTIVITY}

NEM-MEA generation was assayed varying the duration of incubation, amount of cell extract, $\mathrm{pH}$, and substrate concentrations to define enzyme characteristics and optimal assay conditions and to explore the possibility of differences in pantetheinase activity between normal and cystinotic cells. Because of the limited availability of fresh cystinotic WBC not all of the above variables were examined using such cells, although all were investigated using normal WBC and normal and cystinotic fibroblast sonicates.

Figure 2 shows the time course for generation of MEA from PTSH for pooled normal and cystinotic fibroblast sonicates at $\mathrm{pH}$ 7.6. Near linearity is maintained to at least $240 \mathrm{~min}$ in fibroblasts and $90 \mathrm{~min}$ in WBC and easily measurable amounts of MEA are produced at these times. In subsequent assays, these times of incubation were selected unless otherwise specified. There was no difference between the time course of normal and cystinotic fibroblast extracts. Within these time periods, there was strict proportionality of MEA production to amount of cell extract per assay up to at least $1 \mathrm{mg}$ cell protein from normal and cystinotic fibroblasts and at least $2 \mathrm{mg}$ protein from normal leukocytes. Subsequent assays were performed using 0.5 to $1 \mathrm{mg}$ cell protein per assay. Replicate assays varied by less than $5 \%$.

As summarized in Table 1, pantetheinase activity under these conditions was lower in fibroblasts than in WBC, but no substantial differences between cystinotic and normal cell extracts were noted.
Figure 3 shows the patterns of pantetheinase activity in cystinotic and normal fibroblast extracts over a wide $\mathrm{pH}$ range. The $\mathrm{pH}$ optimum is broad and similar in normal and mutant cell sonicates and in fibroblasts and WBC. Relationships between enzyme activity and substrate concentration were quantitated at $\mathrm{pH} 6.5$ for fibroblasts and at $\mathrm{pH} 7.0$ for WBC. There were no significant differences between the normal and cystinotic samples in apparent computer-derived $\mathrm{K}_{\mathrm{m}}$ for substrate in either fibroblasts or WBC (Table 1).

All the data points used in constructing the table and figures represent the mean of at least duplicate, and usually triplicate, determinations.

Because some of the cystinotic children were receiving ascorbic acid during this study and some were not (31), ascorbic acid in amounts both appropriate to and in excess of the estimated blood level were added to both normal and cystinotic WBC and fibroblast extracts in certain control experiments. These amounts of ascorbate did not affect pantetheinase activity (data not shown).

\section{INTRACELLULAR CYSTEAMINE LEVELS}

Endogenous cysteamine was always less than approximately 0.2 $\mathrm{nmole} / \mathrm{mg}$ cell protein in cystinotic and normal fibroblasts. It was thus not possible to test directly whether these cystinotic cells were characterized by cysteamine deficiency. However, when leukocytes were obtained from cystinotic patients who were receiving low doses of oral cysteamine $(42,43)$ and in whom leukocyte cystine content was still grossly elevated, it was possible to quantitate intracellular cysteamine levels. Such values could also be measured in untreated normal and cystinotic WBC's. These data are summarized in Table 2. These results suggest that intracellular cysteamine deficiency is not the cause of cystinosis. The levels of cysteamine in washed cell pellets from untreated cystinotics and from patients receiving exogenous cysteamine in low doses were generally at least as high as those found in cells from normals, yet

\section{PANTETHEINASE FIBROBLAST EXTRACTS}

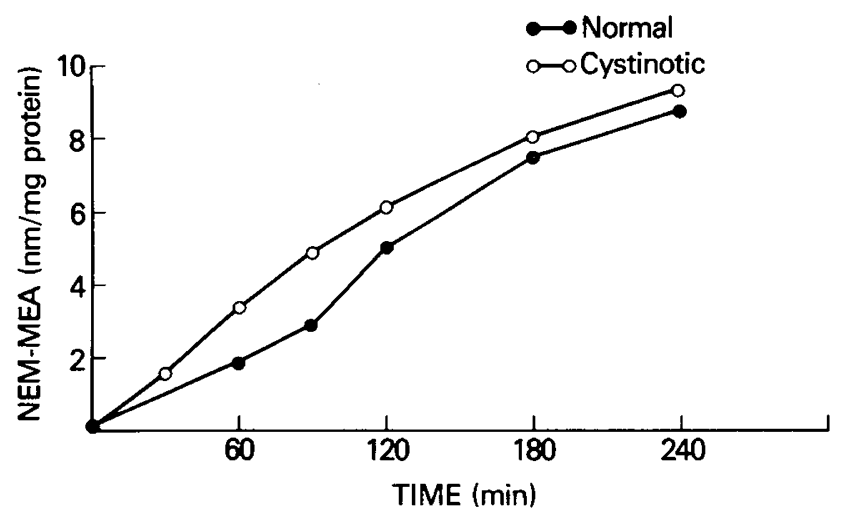

Fig. 2. The time course for generation of cysteamine in normal and cystinotic fibroblast extracts. See text for details.

Table 1. Pantetheinase characteristics in normal and cystinotic cells

\begin{tabular}{lccc}
\hline Type cell & Cysteamine-NEM & $\mathrm{Km}[\mathrm{mM}]$ & $\mathrm{pH}$ optimum \\
\hline WBC & & & \\
Normal & $78 \pm 15^{1}(5)^{2}$ & $0.44 \pm 0.09(5)$ & $6.5-7.5$ \\
Cystinotic & $56 \pm 6.4(4)^{2}$ & $0.28 \pm 0.07(4)$ & $6.5-7.5$ \\
& & & \\
Fibroblasts & & & \\
$\quad$ Normal & $9.4 \pm 1.5(6)^{3}$ & $0.11 \pm 0.04(4)$ & $6-7$ \\
Cystinotic & $7.7 \pm 1.7(6)^{3}$ & $0.03 \pm 0.01(3)$ & $6-7$ \\
\hline
\end{tabular}

\footnotetext{
${ }^{1}$ Mean \pm S.E.

${ }^{2} \mathrm{nmole} / \mathrm{mg}$ protein/90 min.

${ }^{3} \mathrm{nmole} / \mathrm{mg}$ protein $/ 240 \mathrm{~min}$. (no. of lines). All differences, $P>0.05$.
} 


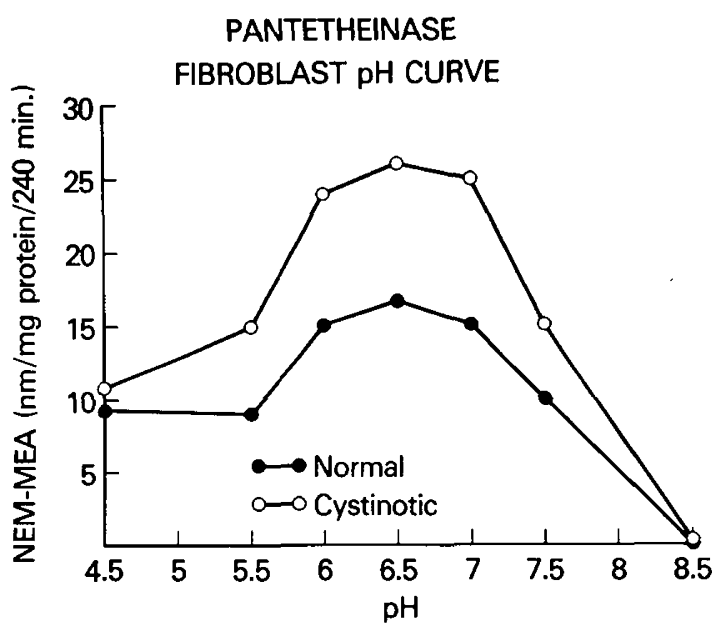

Fig. 3. Pantetheinase activity as a function of $\mathrm{pH}$ in cystinotic and normal fibroblast extracts.

Table 2. Cysteamine and cystine content of leukocytes from normal and cystinotic subjects and cystinotics receiving oral cysteamine at doses which did not reduce leukocyte cystine content

\begin{tabular}{lccc}
\hline & No. of & $\begin{array}{c}\text { Cysteamine } \\
\text { (range) } \\
\text { (nmole/mg } \\
\text { protein) }\end{array}$ & $\begin{array}{c}\text { Cystine } \\
\text { (range) } \\
(1 / 2 \mathrm{nmole} / \mathrm{mg} \\
\text { protein) }\end{array}$ \\
\hline Normal & 5 & $0.27-1.1$ & $<0.5$ \\
$\begin{array}{l}\text { Cystinotic, no } \\
\text { cysteamine } \\
\text { therapy }\end{array}$ & 5 & $<0.2-4.5$ & $2.0-12.4$ \\
$\begin{array}{l}\text { Cystinotic, low } \\
\text { dose cysteamine } \\
(10 \mathrm{mg} / \mathrm{kg} / \text { day) }\end{array}$ & 4 & $1.5-3.5$ & $3.1-21$ \\
\hline
\end{tabular}

the former simultaneously had grossly elevated leukocyte cystine levels whereas the latter did not.

\section{DISCUSSION}

There is no evidence for decreased enzymatically catalyzed cystine reduction or metabolism in cystinotic cells $(21,27-29,41)$ and little support for the presence of significant amounts of cystine-reducing activity in either normal or cystinotic lysosomes $(35,40,46,47,49)$. Cystinotic cells have normal reduced glutathione content $(27,34)$. Because cysteamine supplied exogenously can reduce cystinotic intracellular cystine levels to near normal (42), the possibility that cystinosis might be due to a defect in endogenous MEA generation needed critical evaluation. Demonstration of a defect in MEA production in cystinosis might be accomplished by measurement of pantetheinase activity and/or of cell MEA levels.

The only known source of endogenous MEA is breakdown of pantetheine, involved in coenzyme A catabolism (Figure 1). This degradative pathway permits cysteamine generation and pantothenate recovery. Enzymatic degradation of CoA was described by Lipmann et al. and Novelli et al. (25) and subsequent important studies related to pantetheine catabolism have been performed by Dupre et al. (using horse kidney) (4, 6, 8, 11, 13-17) and Abiko et al. (rat liver and kidney) $(1-3,26,36)$. In rat liver, CoA is degraded to phosphopantetheine by a lysosomal acid phosphatase and a nuclear and microsomal plasma membrane pyrophosphatase. Further dephosphorylation to PTSH probably occurs before a specific and irreversible amidase (pantetheinase) catalyzes cleavage to PoA and MEA. Pantetheinase activity is located primarily in the microsomal-lysosomal fraction of rat liver and rat kidney (2).

Measurement of MEA levels directly in rodent tissues has been reported by Huxtable et al. (20). MEA reacted with phthalic anhydride- $1-{ }^{14} \mathrm{C}$ to yield $\mathrm{N}$-(2-thioethyl)-phthalimide- $-{ }^{14} \mathrm{C}$, which was isolated by thin-layer chromatography and identified by mass spectrometry. Estimated levels of MEA in rats were $0.17 \mathrm{nmole} / \mathrm{g}$ tissue in kidney, 0.21 in liver, 0.25 in muscle, 0.68 in brain and 2.61 in heart. With this method, large tissue samples were required, and recoveries of exogenous MEA were less than 3\%. These studies, however, provided evidence that MEA is an endogenous metabolite.

We describe here a new method for measuring cysteamine either directly in biologic samples or as an end product of pantetheinase activity using reduction with DTT, reaction with NEM, and quantitation of MEA-NEM on an amino acid analyzer. The method is rapid, nonradioactive, and easy to use on small samples. Exogenous MEA is quantitatively recovered in this system.

Utilizing this assay system, cystinotic cell extracts were not different from normal with regard to total activity, apparent $\mathrm{K}_{\mathrm{m}}$, or $\mathrm{pH}$ optimum of pantetheinase. These observations suggest a normal capacity for cysteamine generation in cystinotic cells and are the first of which are aware to demonstrate PTSH cleavage activity in human tissues.

Furthermore, we were able to directly measure MEA content in leukocytes from normal subjects and from cystinotic patients receiving either no cysteamine or doses of cysteamine inadequate to normalize their leukocyte cystine content. These results also provide no support for the hypothesis that cystinosis is caused by endogenous cysteamine deficiency.

The studies of human pantetheinase activity reported here are derived from analysis of unpurified preparations. Further characterization of pantetheinase purified from human tissues would be of considerable interest, but is unlikely to alter the fundamental conclusion of our studies with regard to cystinosis. The present investigations indicate that a defect in cysteamine generation is most unlikely to represent the fundamental molecular lesion in this disease.

\section{REFERENCES AND NOTES}

1. Abiko, Y.: Investigations on pantothenic acid and its related compounds, II. Biochemical studies. (4) Separation and substrate specificity of pantothenate kinase and phosphopantothenoyl-cysteine synthetase. J. Biochem., 61:290 (1967).

2. Abiko, Y.: Metabolism of coenzyme A. In: D. M. Greenberg: Metabolism of Sulfur Compounds. (Metabolic Pathways, Ed. 3, Vol. 7) p. 1 (Academic Press Inc., New York, 1975.)

3. Ashida, S. I., and Abiko, Y.: Protective effect of pantetheine on experimental thrombocytopenia in the rat. Thromb. Diath. Haemorrh., 33: 528 (1975).

4. Bellussi, L., Dupre, S., Pecci, L., and Santoro, L.: The stereospecificity of enzymatic pantetheine hydrolysis. Physiol. Chem. Phys., 6: 505 (1974)

5. Brown, G. M.: Assay and distribution of bound forms of pantothenic acid. J. Biol. Chem., 234: 379 (1958)

6. Cavallini, D., Dupre, S., Gruziani, M. T., and Tinx, M. G.: Identification of pantetheinase in horse kidney extract. FEBS Lett., $1: 119$ (1968).

7. Cavallini, D., Scandurra, R., and DeMurcu, C.: The enzymatic oxidation of cysteamine to hypotaurine in the presence of sulfide. J. Biol. Chem., 238: 2999 (1963).

8. Cavallini, D., Scandurra, R., Dupre, S., Federici, G., Santoon, L., Ricci, G., and Barra, D.: Alternate pathways of taurine synthesis. In: R. Huxtable, A. Barbeau: Taurine p. 59 (Raven Press, New York, 1976).

9. Cavallini, D., Scandurra, R., Dupre, S., Santuro, L., and Barra, D.: A new pathway of taurine biosynthesis. Phys. Chem. Phys., 8: 157 (1976).

10. Craig, J. A., and Snell, E. E.: The comparative activities of pantetheine, pantothenic acid and coenzyme A for various microorganisms. J. Bacteriol., 61: 283 (1951).

11. Dupre, S., Antonucci, A., Piergross, P., Aurel, M. et al: A pH-Stat method for pantetheinase activity determination. J. Biochem., 25: 229 (1976).

12. Dupre, S., and DeMarco, C.: Activity of some animal tissues on the oxidation of cysteamine to hypotaurine in the presence of sulphide. Hal. J. Biochem, 13: 386 (1964)

13. Dupre, S., Grawata, F., Syntomo, L., Scandurra, R., Federici, G., and Cavallini, D.: In vitro enzymatic conversion of pantothenylcysteine-4'-phosphate into cysteamine. J. Biochem., 24: 369 (1975).

14. Dupre, S., Gruziani, M. T. and Rossi, M. A.: A new method for the determination of enzymatic pantetheine-splitting activity. J. Biochem., 19: 132 (1970).

15. Dupre, S., Gruziani, M. T., Rossi, M. A., Fibi, A., and DelGrusso, E.: The enzymatic breakdown of pantetheine to pantiothenic acid and cysteamine. Eur. J. Biochem., 16: 571 (1970).

16. Dupre, S., Rose, M. A., Belluss, L., Barbun, E., and Scandurru, R.: Studies on pantethinase. 9th Internatl. Cong. Biochem., Stockholm. Abst. 2028 (1973). 
17. Dupre, S., Rose, M. A., Belluss, L., DelGrosso, E., and Cavallini, D.: The substrate specificity of pantetheinase. Eur. J. Biochem., 40: 103 (1973).

18. Ewetz, L., and Sorbo, B.: Characteristics of cysteine-sulfinate forming enzyme system in rat liver. Biochim. Biophys. Acta, 128: 296 (1966).

19. Federici, G., Fiori, A., Costa, M., Barboni, E., and Dupre, S.: Studies on cysteamine oxygenase. 9th Internatl. Cong. of Biochem., Stockholm. Abst. 74a (1973).

20. Huxtable, R., and Bressler, R.: The metabolism of cysteamine to taurine. In: R Huxtable, A Barbeau: Taurine, p. 45. (Raven Press, New York, 1976).

21. Kaye, C., and Nadler, H. L.: Enzymatic reduction of cystine and glutathione in cultivated human fibroblasts from normal subjects and patients with cystinosis. J. Lab. Clin. Med., 86: 422 (1975).

22. Lombardini, J. B., Singer, T. P., and Boyen, P. D.: Cysteine oxygenase. II. Studies on the mechanism of the reaction with oxygen. J. Biol. Chem., 244: 1172 (1969).

23. Lowry, O. H., Rosebrough, N. J., Farr, A. L., and Randall, R. J.: Protein measurement with the Folin phenol reagent. J. Biol. Chem., 193: 265 (1951).

24. Mudd, S. H.: Determination of sulfite in biological fluids: the usefulness of radioactive $N$-ethylmaleimide. Anal. Biochem., 22: 242 (1968).

25. Novelli, G. D., Schmetz, F. J., and Kaplan, N. O.: Enzymatic degradation and resynthesis of coenzyme A. J. Biol. Chem., 206: 530 (1954).

26. Onu, S., Kameda, K., and Abiko, Y.: Metabolism of pantethine in the rat. J. Nutr. Sci. Vitaminol., 20: 203 (1974).

27. Oshima, R. G., Rhead, W. J., Thoene, J. G., and Schneider, J. A.: Cystine metabolism in human fibroblasts. J. Biol. Chem., 251: 4287 (1976).

28. Patrick, A. D.: The degradative metabolism of $\mathrm{L}$-cystine and $\mathrm{L}$-cysteine in vitro by liver in cystinosis. Biochem. J., 83: 248 (1962).

29. Patrick, A. D.: Deficiencies in SH-dependent enzymes in cystinosis. Clin. Sci., 28: 427 (1965).

30. Schneider, J. A., Bradley, K. H., and Seegmiller, J. E.: Increased cystine in leukocytes from individuals homozygous and heterozygous for cystinosis. Science (Wash. D. C.), 157: 1321 (1967).

31. Schneider, J. A., Schlesselman, J. J., Mendoza, S. A., Orloff, S., Thoene, J. G., Kroll, W. A., Godfrey, A. D., and Schulman, J. D.: Ineffectiveness of ascorbic acid therapy in nephropathic cystinosis. N. Eng. J. Med., 300: 756 (1979).

32. Schneider, J. A., Schulman, J. D., and Seegmiller, J. E.: Cystinosis and the Fanconi syndrom. In: J. B. Stanbury, J. B. Wyngaarden, D. S. Frederickson: The Metabolic Basis of Inherited Disease. Ed. 4, p. 1660 (McGraw-Hill Book Co., Inc., New York, 1978).

33. Schulman, J. D., ed.: Cystinosis. DHEW Publ. No. (NIH) 72-2491 (1973)

34. Schulman, J. D., Bradley, K., and Seegmiller, J. E.: Cystine: compartmentalization with lysosomes in cystinotic leukocytes. Science (Wash. D. C.), 166: 1152 (1969).

35. Schulman, J. D., and Bradley, K. H.: Metabolism of amino acids, peptides, and disulfides in the lysosomes of fibroblasts cultured from normal individuals and those with cystinosis. J. Exp. Med., I32: 1090 (1970).

36. Schulman, J. D., Schneider, J. A., Bradley, K. H., and Seegmiller, J. E.: Cystine, cysteine and glutathione metabolism in normal and cystinotic fibroblasts in vitro and in cultured amniotic fluid cells. Clin. Chim. Acta, 37: 53 (1972).

37. Shimizu, M., and Abiko, Y.: Investigations on pantothenic acid and its related compounds. II. Biochemical studies. (1) Biosynthesis of coenzyme-A from pantothenate, pantethine and from S-benzoylpantetheine in vitro and in vivo. Chem. Pharm. Bull. (Tokyo), 13: 189 (1965).

38. Skeggs, H. R., and Wright, L. D.: The use of Lactobacillus arabinosus in the microbiological determination of pantothenic acid. J. Biol. Chem., 156: 21 (1944).

39. Solberg, O., Hegru, I. K., and Clausen, O. G.: Pediococcus acidilactici NC I B6990: a new test organism for microbiological assay of pantothenic acid. J. Appl. Bacteriol., 34: 119 (1975).

40. States, B., and Segal, S.: Distribution of glutathione-cystine transhyrogenase activity in subcellular fractions of rat intestinal mucosa. Biochem. J., l13: 443 (1969).

41. States, K., Hannis, D., and Segal, S.: Patterns of cystine reduction by fibroblasts from normal and cystinotic children. Pediatr. Res., 11: 685 (1977).

42. Thoene, J. G., Oshima, R. G., Crawhall, J. G., Olson, D. L., and Schneider, J. A.: Intracellular cystine depletion by aminothiols in vitro and in vivo. J. Clin. Invest., $58: 180$ (1976).

43. Thoene, J., Schulman, J. D., and Schneider, J. A.: Unpublished experiences.

44. Tietze, F.: Disulfide reduction in rat liver I: Evidence for the presence of nucleotide-dependent disulfide reductase \& GSH-disulfide transhydrogenase activities in the high-speed supernatant fraction. Arch. Biochem. Biophys., 138: 177 (1970).

45. Tietze, F.: Disulfide reduction in rat liver. II Chromatographic separation of nucleotide-dependent disulfide reductase \& GSH disulfide transydrogenase activities of the high-speed supernatant fraction. Biochim. Biophys. Acta, 220: 449 (1970).

46. Tietze, F.: Enzymic reduction of cystine and other disulfides. In: Cystinosis. p. 147. DHEW Publ. No. (NIH) 72-2491 (1973).

47. Tietze, F., Bradley, K. H., and Schulman, J. D.: Enzymic reduction of cystine by subcellular fractions of cultured and peripheral leukocytres from normal and cystinotic individuals. Pediatr. Res., 6: 649 (1972).

48. Wainer, A.: The production of cysteine-sulfinic acid from cystine in vitro. Biochim. Biophys. Acta, 104: 405 (1965).

49. Wendell, P. H.: Distribution of glutathione reductase and detection of glutathione-cystine transhydrogenase in rat tissues. Biochim. Biophys. Acta, 159: 175 (1968).

50. EDTA and anaerobic conditions were used during the assay to minimize possible conversion of cysteamine to its oxidation products by any MEA oxygenase activity in the cell extracts. No systematic effort was made to quantitate such oxygenase activity, but it was observed in several experiments that anaerobic assay conditions, and/or addition of EDTA or ortho-phenanthroline, yielded maximal quantities of cysteamine under the assay conditions used (data not shown).

51. Presented in part at the annual meeting of the American Society of Human Genetics, Vancouver, B.C., October, 1978.

52. Requests for reprints should be addressed to: Dr. Joseph D. Schulman, Department of Health, Education, and Welfare, Public Health Service, National Institutes of Health, Bldg. 10, Room 13N 260, Bethesda, MD 20205 (USA).

53. Received for publication August 14, 1980.

54. Accepted for publication November 20, 1980 